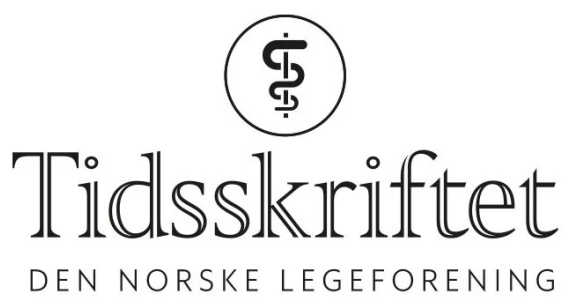

\title{
Endret farmakokinetikk ved hypotermi
}

NYHETER

INGRID SKINLO ROKSTAD

Email: ingrid.rokstad@legeforeningen.no

Tidsskriftet

Nedkjøling påvirker legemidlers farmakologi og kan blant annet gi endret effekt av sedativer og analgetika hos hypoterme pasienter. 


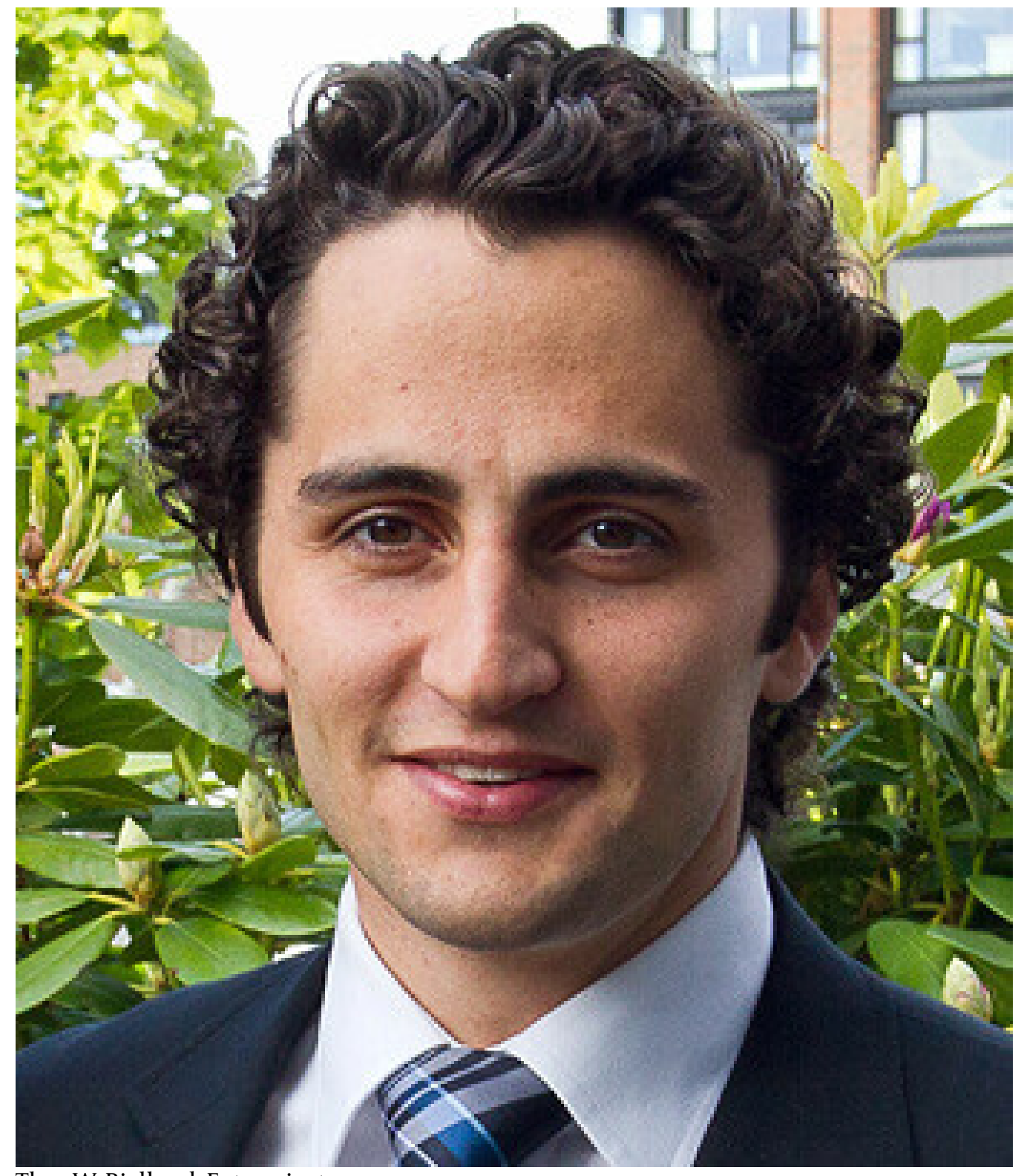

Thor W. Bjelland. Foto privat

Terapeutisk hypotermi har blitt standard behandling av komatøse pasienter etter vellykket hjerte-lunge-redning etter hjertestans. Behandlingen reduserer dødelighet og andelen pasienter med alvorlige hjerneskader. Den består i å senke kroppstemperaturen til $33-34^{\circ} \mathrm{C}$ i 12-24 timer. I forbindelse med dette gis pasienten sedativer og analgetika.

- Nedkjøling induserer en rekke fysiologiske endringer som kan påvirke legemidlers kliniske farmakologi. Det finnes svært få studier der man har sett på effekten av dette hos pasienter, forteller Thor W. Bjelland.

Hans avhandling baserer seg på to kliniske studier. I den første studien ble farmakokinetikken til morfin, midazolam, fentanyl og propofol hos pasienter behandlet med terapeutisk hypotermi sammenliknet med den hos normoterme intensivpasienter av samme alder og kjønn og med lik varighet av infusjoner.

- Resultatene våre viser at clearance av morfin, fentanyl og propofol var signifikant langsommere hos de hypoterme pasientene, noe som kan innebære fare for akkumulasjon, sier Bjelland. - Dette innebærer at en lavere dosering kan gi mindre symptomer på overdosering, forbruk av vasopressorer og minske risikoen for langsom oppvåkning. Studie II sammenlikner kombinasjonen av propofol og remifentanil med midazolam og fentanyl hos 59 pasienter behandlet med terapeutisk hypotermi. Her fant vi signifikant kortere tid til opphevet effekt for propofol og remifentanil, noe som er viktig i en fase der man ønsker å skille sedasjon via legemidler fra organisk hjerneskade, avslutter han. 


\section{Disputas}

Thor W. Bjelland disputerte for ph.d.-graden ved Norges teknisk-naturvitenskapelige universitet 14.6. 2012. Tittelen på avhandling er Pharmacological aspects of therapeutic hypothermia.

Publisert: 27. november 2012. Tidsskr Nor Legeforen. DOI: 10.4045/tidsskr.12.116o

(C) Tidsskrift for Den norske legeforening 2023. Lastet ned fra tidsskriftet.no 26. april 2023. 